\title{
NTR Anna Canteens: A Boon to Urban Poor of Andhra Pradesh, India
}

\author{
Dr. Mutluri Abraham
}

Post Doctoral Fellow - ICSSR, Department of Social Work, Andhra University, Vis akhapatnam, Andhra Pradesh, India

Email: vijjyabhi@gmail.com

\begin{abstract}
Food is a basic need for every human being. Reports stated that the urban poor are deprived for the basic food and many people in urban areas are malnourished and become baggers due to hungry, poverty and lack of food. To solve this problem, Government of Andhra Pradesh has introduced NTR Anna Canteens Scheme in Andhra Pradesh in July 2018 to provide the ready food at subsidised price to the urban poor. These canteens provide the breakfast, lunch and dinner to the urban poor at its premises. It is Rs. 5/- for each meal (Breakfast Rs.5/, Lunch Rs.5/- and Dinner Rs.5/-). Urban poor have the breakfast, lunch and dinner sufficiently with Rs.15/- and do their works/jobs in Andhra Pradesh. First, in 2011, the government of Jharkhand was started the similar scheme. But after one year it was stopped due to fewer budgets. Then the former CM of Tamil Nadu Smt. Jaya Laitha was started Amma Canteen in June 2013. She continued this scheme successfully and it becomes a model for many states of India. It also became a vote bank scheme for many state governments. Government of Andhra Pradesh started 100 NTR Anna Canteens in different urban cities of Andhra Pradesh in July 2018. This scheme was handed over Akshya Patra Foundation (NGO) to implement in Andhra Pradesh. According to the officials, on an average Rs.73/- is being spent for food per head per day at the canteen. The beneficiaries pay only Rs.15/-for breakfast, lunch and dinner, while the remaining cost of Rs.58/- spent by the Government of Andhra Pradesh. The study found that this scheme is useful to the many unemployed youth, bachelor students and employees, workers in unorganised sectors, people staying in hospitals etc. People are having sufficient food. The study found that customers were highly satisfied with Anna Canteens. This scheme is indirectly helping to increases the savings of the urban poor. Reduced malnourishments and Increased health standards of urban poor and unemployed youth.
\end{abstract}

Keywords-NTR Anna Canteens, Urban Poor, Amma Canteen.

\section{INTRODUCTION}

Food is a basic need for every human being. Reports reported that the urban poor are deprived for the basic food, malnourished and become baggers due to hungry, poverty and lack of food. According to 2014 Global Hunger Index, India ranks 55 out of the world's 120 hungriest countries, much behind other South Asian countries such as Nepal and Sri Lanka. It is very sad to know that about 25 per cent of Indians go to sleep without dinner due to poverty (Lal, 2016). The major reasons for the food insecurity in urban areas are raising urban inequality, an increasingly insecure workforce with contract employ ment, growth of slums and slum population. This was created lot of insecurity among domestic workers, street vendors, auto drivers and unskilled workers constitute a sizeable population in the urban centers of India in poorer access to safe and nutritious food. Food is available in the urban areas in the name of mess, hotels, restaurants etc. But the cost is very high in those hotels and the common man may not affordable due to less income. In this context the Government of Andhra Pradesh has started NTR Anna canteens to provide the food to the urban poor. It is a poverty elevation programme like civil supply public distribution system.

'NTR Anna Canteens' is a Government Scheme started by Govern ment of Andhra Pradesh in July 2018 to provide the quality food at highly subsidized price to the urban poor. NTR is a name 'Nandamuri Taraka Ramarao' founder president of Telugu Desam Party (1983) and familiar Telugu film star. Anna Means elder brother in Telugu. To remember the trustworthiness of NTR, the state Government named as 'NTR Anna Canteens'. The purpose of this scheme is to provide food to poor people on affordable cost. The motto of this scheme is to provide 
"Subsidized Hygienic and Affordable Food for Poor People."

In Andhra Pradesh, June 2016 one NTR Anna Canteen (Pilot) was started in Velagapudi, Amaravathi for the government employees who shifted from Hyderabad due to state bifurcation, and then in July 2018 Government of Andhra Pradesh started 100 NTR Anna Canteens in different urban cities of Andhra Pradesh. The state government proposed to construct 103 more canteens in other parts of Andhra Pradesh. The canteens were permanently constructed in the Government land. These canteens provide the breakfast, lunch and dinner to the urban poor at its premises. It is estimated that, for running 203 canteens (100 existing and 103 proposed), the government will have to spend Rs 130 crore per annum for food. For construction of the buildings they spent nearly 388.5 crores. The target of the government is to 2.5 lakh plates of food a day on an average and as of now 70,000 plates of food is being served. The preparation of food is being monitored real-time governance. The electronic token system is being followed in Anna Canteens for transparency. Sterilised plates and purified water will be provided to the customers. They capture the photo of the customer. CC Cameras are also arranged in Anna Canteen premises.

In Andhra Pradesh, Anna Canteens Scheme was handed over to Akshya Patra Foundation (NGO) to preparation of the food and serving the food in Anna Canteens. Akshya
Patra Foundation is also implementing the Mid-Day Meal Programme to over 1.76 million children from 15,024 schools across 12 states in India. It is a popular voluntary organization and also associated with ICDS programme in Andhra Pradesh and providing food to pregnant women and children. Akshaya Patra has 43 kitchens spread across 12 states in India. According to the officials, on an average Rs.73/- is being spent for food per head per day at the canteen. The beneficiaries pay only Rs.15/- for breakfast, lunch and dinner, while the remaining cost of Rs.58/spent by the Government of Andhra Pradesh. Lunch and dinner at these canteens include 400 grams of rice, a cup of curry, $120 \mathrm{grams}$ of sambar, dal and $75 \mathrm{grams}$ of curd along with a pickle. For breakfast, a plate of three idli or poori or pongal is served for just Rs. 5. The distribution of food is on self-service with token system, which will be monitored by electronic display in a transparent manner. Ramp will be provided for physically challenged people for easy access with dining facility separately provided.

Anna Canteens was started with the inspiration of Amma Canteens which was started in Tamila Nadu in 2013. Providing food through canteens by the Government at low price is not a new scheme to India but it is a new scheme to Andhra Pradesh. The same models of schemes are already implemented and implementing in many states of India. The below table presents the information about the list of state governments are providing the food at low price for the urban poor in India.

Table.1: List of the states providing the food at low price to the urban poor in India

\begin{tabular}{|c|c|c|c|c|}
\hline $\begin{array}{l}\text { S. } \\
\text { No }\end{array}$ & State & $\begin{array}{l}\text { Name of the } \\
\text { Canteen }\end{array}$ & $\begin{array}{l}\text { Date and year of } \\
\text { Establishment }\end{array}$ & Particulars \\
\hline 1 & Jharkhand & $\begin{array}{l}\text { Mukhyamantri Dal } \\
\text { Bhat Yojana (Chief } \\
\text { Minister's dal rice } \\
\text { scheme) }\end{array}$ & $\begin{array}{l}\text { June, } 2011 \text { they started } \\
370 \text { centres. But closed } \\
\text { after one year. Again } \\
\text { they started in } 2016\end{array}$ & $\begin{array}{l}\text { Around } 22.5 \text { lakh people are being fed and the } \\
\text { government spends Rs } 25 \text { crore annually. }\end{array}$ \\
\hline 2 & Tamil Nadu & $\begin{array}{l}\text { Amma Canteen/ } \\
\text { Unavagam }\end{array}$ & $\begin{array}{l}\text { February } 2013 \\
400 \text { Amma Canteens }\end{array}$ & $\begin{array}{l}\text { ₹ } 1 \text { for an idly, ₹5 for a plate of sambar rice, ₹5 for a } \\
\text { plate of "Karuvapellai Satham" (Curry leaves rice) } \\
\text { and ₹3 for a plate of curd rice }\end{array}$ \\
\hline 3 & Odisha & Ahar Yojana & $\begin{array}{l}\text { April } 2015 \\
111 \quad \text { centres serving } \\
\text { lunch in all } 30 \text { districts }\end{array}$ & $\begin{array}{l}\text { It provides lunch at Rs.5/- for the urban poor. Only } \\
\text { one item i.e. 'dalma' - a watery mixture of lentil and } \\
\text { boiled vegetables. }\end{array}$ \\
\hline 4 & Uttarakhand & $\begin{array}{l}\text { Indira Amma } \\
\text { Canteens, }\end{array}$ & November 2015 & This scheme is providing food at Rs 20 per plate. \\
\hline 5 & Telangana & GHMC Annapurna & May 2016 & Provide food at Rs. 5 "At present, they feed to \\
\hline
\end{tabular}




\begin{tabular}{|c|c|c|c|c|}
\hline & & Canteens & 50 canteens & 15,000 people daily \\
\hline 6 & Uttar Pradesh & $\begin{array}{l}\text { Samajwadi } \\
\text { Canteens } \\
\text { 'Annapurna } \\
\text { Bhojnalayas' Yogi } \\
\text { tali }\end{array}$ & $\begin{array}{l}\text { November } 2016 \\
\text { / April } 2017\end{array}$ & $\begin{array}{l}\text { Provide breakfast for ₹ } 3 \text { and Lunch is available for } \\
\text { just Rs } 5 \text {.The daily menu includes daal, vegetable, } \\
\text { four chapatis, rice, pickles, a piece of sweet petha. }\end{array}$ \\
\hline 7 & Rajasthan & Annapurna Rasoi & $\begin{array}{l}\text { December } 2016 \\
80 \text { vans in } 12 \text { cities of } \\
\text { Rajasthan }\end{array}$ & $\begin{array}{l}\text { Provides breakfast for ₹ } 5 \text { and lunch and dinner for } \\
₹ 8 \text {. }\end{array}$ \\
\hline 8 & New Delhi & $\begin{array}{l}\text { Aam Admi Canteen } \\
\text { Atal Jan Ahar } \\
\text { Yojana }\end{array}$ & $\begin{array}{l}\text { January } 2017 \\
\text { December } 2017 \\
225 \text { Canteens }\end{array}$ & $\begin{array}{l}\text { Provide meals for Rs } 5 \text { to } 10 . \& \text { Started by Municipal } \\
\text { Corporation Delhi }\end{array}$ \\
\hline 9 & $\begin{array}{l}\text { Madhya } \\
\text { Pradesh }\end{array}$ & $\begin{array}{ll}\text { Deendayal } & \\
\text { Antyodaya } & \text { Rasoi } \\
\text { Kitchens'. } & \\
\end{array}$ & April 2017 & $\begin{array}{l}\text { Breakfast, Lunch and Dinner will be provided. Each } \\
\text { one is at Rs.5/- }\end{array}$ \\
\hline 10 & Karnataka & Indira canteen & $\begin{array}{l}\text { August } 2017 \\
100 \text { canteens }\end{array}$ & Lunch is available at Rs.5/- \\
\hline 11 & West Bengal & Janta Meals & August 2017 & $\begin{array}{l}\text { Rs.10/, vegetable Thali, everyday they feeding } \\
40,000 /-\end{array}$ \\
\hline 12 & Haryana & $\begin{array}{l}\text { 'Antyodaya Aahaar } \\
\text { Yojana'. }\end{array}$ & $\begin{array}{l}\text { February 2018, } 23 \\
\text { canteens was started }\end{array}$ & $\begin{array}{l}\text { Rs } 10 \text { per meal to all poor and needy } \\
\text { "Each food packet weighing } 730 \mathrm{gm} \text { will include four } \\
\text { chapattis, rice, daal, seasonal vegetables, curd/raita, } \\
\text { green chutney and jagery. }\end{array}$ \\
\hline 13 & $\begin{array}{l}\text { Andhra } \\
\text { Pradesh }\end{array}$ & $\begin{array}{ll}\text { NTR } & \text { Anna } \\
\text { canteens \& } & \\
\text { Rajanna } & \text { Canteens } \\
(2017) & \end{array}$ & $\begin{array}{l}\text { June } 2016 \text { one canteen } \\
\text { at Amaravathi. In July } \\
2018 \quad \text { opened } \\
\text { canteens }\end{array}$ & $\begin{array}{l}\text { Breakfast Rs.5/- (Limited) } \\
\text { Lunch at Rs. 5/- (Limited) } \\
\text { Dinner at Rs.5/- (Limited) } \\
\text { Serving for } 70000 \text { people of urban areas }\end{array}$ \\
\hline
\end{tabular}

The data in the above table reveals that the canteens scheme was started by the Government of Jarkhand in 2011. The same model has taken over by the Government of Tamila Nadu. Government of Tamila Nadu got success in running of the scheme and they involved Self Help Groups to run this Amma Canteens. So that the scheme got vide circulation in India. Many politicians felt that it is a vote bank scheme. So that many state governments has started canteens in the country. Government of Andhra Pradesh started Anna Canteens in July 2018. Interestingly the Opposition Party (YSRCP Party) of Andhra Pradesh has also started Rajanna Canteens in Prodduture and Mangalagiri and they are providing the food at Rs.4/-.

\section{REVIEW OF LITERATURE}

Ashok Kumar \& D. Krishnan (2013) conducted a study on perception of consumers towards "Amma Unavagum" with special Reference to Vellore city, Tamilnadu, India. The main objective of the study is to know the perception of the consumers towards "A mma unavagam. The study collected the data 200 consumers in Vellore city. The study found that majority of the respondents belongs to 25 to 45 years age group and $83 \%$ respondents are male and majority of the respondent's income is below Rs.5000/-. 56\% of the respondents agree that foods are being prepared in hygienic manner at A mma unavagam A mma unavagam' has a great positive impact among the middle class people who are living in the Vellore city. If the same strategy is continued or even improved, this scheme will create a great 'good will' on the govt. of Tamilnadu.

A.R. Nithya et al. (2018) conducted a study on Amma Canteens and its implementation in Tamil Nadu. The study found that the Amma canteens are providing the food to the 
urban poor and at the same time the scheme involved the women of self help group. It helps the women livelihood.

Tata Institute of Social Sciences (2018) conducted a study with the title of Food and Welfare: A Case Study of Annapurna Canteens in Hyderabad. The objective of the study is to understand the implementation of Annapurna Canteens in Hyderabad. These are als o similar canteens like Anna Canteen. The study is based on a mix of quantitative and qualitative research design in order to conduct an objective as well as subjective exploration of Annapurna canteens. Primary information was gathered through nonparticipant observation and through in-depth structured questionnaires. The study found that most beneficiaries were employed and a large number of them engaged in the informal sector as auto drivers, vegetable vendors, carpenters, plumbers, etc. More than half i.e., $53 \%$ of beneficiaries were migrants hailing from different parts of India including Uttar Pradesh, Bihar, Odisha, Maharashtra, Andhra Pradesh as well as other regions from Telangana.

\section{METHODOLOGY}

It is a new topic. No study was conducted on this topic because the canteens scheme was introduced in Andhra Pradesh in July 2018 only. But the researcher reviewed the similar schemes in other states of India for the literature. The main objective of the present study is to study the socio-economic profile of the respondents having food in Anna Canteen. The study also aimed to understand the satisfactory levels of customers of Anna Canteens. This study conducted in 4 Anna Canteens of Visakhapatnam which are located in China Waltair, M.V.P. Colony, Jagadamba and Anakapalli. Purposive Sampling method was adopted for this study and collected the data from 92 beneficiaries of Anna Canteens through structured interview schedule. The data were analyzed through Ms-Excel 2010. The study was conducted in the month of February 2019.

\section{Process of Food Transportation in Visakhapatnam}

Akshya Patra Foundation one of the reputed NGOs in India has a cooking industry in Visakhapatnam. Here the food will be prepared and send to the Anna Canteens by Auto Rikshaws. The auto driver has the responsibility to deliver the food at right time. Then the auto driven will collect the vesicles of the previous section and handover to Akshya Patra Foundation. Then they send another section food material through the Auto. It is a rotation activity for auto drivers. When the demand is less in the canteens, the food will be send back to the Akshya Patra Foundation every day. They distribute that food to the beggars are street children. Based on the demand of the previous day, Akshya Patra Foundation will send the food to Anna Canteen. Each canteen providing the food to $300-500$ people in its premises based on the demand.

\section{Major Findings}

1. Accessing Government Schemes are difficult in Andhra Pradesh and India but accessing this scheme is very easy. People who have hungry may walk-in to Anna Canteen and access the food. No identification card is required to access this scheme. So that the scheme reached grassroots and the poor.

2. The study found that majority $(82 \%)$ of the respondents is male.

3. The study found that majority of the respondents belongs to the back ward class. It may be reason that the north Andhra has more number of back ward class population.

4. The study found that majority $(58 \%)$ of the respondents is unemployed youth, bachelor students, auto drivers and youth preparing for the competitive examinations. The remaining respondents are the workers in unorganised sectors, people staying in hospitals etc. the bachelors stated that before Anna Canteen the bachelors and unemployed youth prepare / cook rice and bring the curry from the curry points. But after this scheme they are simply coming and accessing the food in Anna Canteen.

5. The food preparation problems of bachelors and the unemployed youth preparing for competitive examinations were reduced. Otherwise it is very difficult for the bachelors to preparation of the food. It consumes lot of their precious time.

6. The study found that majority $(89 \%)$ of the respondents was satisfied with the food quality, quantity and cleanliness in Anna Canteens. The food providing in Anna Canteens is sufficient for the people. The persons who eat more they may take another token by paying of Rs.5/- . The unlimited tokens are giving by the staff of Anna Canteens. It is observed that the respondents take two tokens at the time of breakfast.

7. The study found that majority of the customers who taking the food in Anna Canteens are poor 
and their income is less than Rs.6000/- per a month.

8. The study found that majority (75\%) of the respondents eats food in Anna Canteen 3-5 days in a week. Repeated customers are very high for Anna Canteens. Most of them are accessing the food at Dinner time. All youth and bachelors are coming together and having the food in Anna Canteens.

9. Majority of the Anna Canteens was established near to Hospitals. The people accompanying the patients and staying in hospitals are coming to the Anna Canteens to access the food.

10. Majority $(68 \%)$ of the respondents stated that they don't have any self stigma to stand in the lane. They have the self stigma in beginning days, now majority of the people are not having the self stigma. So me people have self stig ma and they felt that it is a less cost food. The feel that their standard is very high and they take food at restaurants.

11. It is found that majority $(52 \%)$ of the respondents stated that increased savings, and improved health standards after Anna Canteen. Previously they spent at least Rs.100/- per day for food, now it is Rs.15/- only.

12. There is a myth about Anna Canteens and low price food. i.e. 'After Anna Canteens People are not doing the work'. But it is not true. Majority $(59 \%)$ of the respondents stated that it is a myth and misconception, because $(59 \%)$ of the respondents stated that they are doing the work regularly. And earning money. But some of the respondents are spending the more money to alcohol and taking the food at low price at Anna Canteen.

13. Government of Andhra Pradesh handed over the scheme to Akshya Patra Foundation (NGO). It is also implementing the Mid-Day Meal Programme to over 1.76 million children from 15,024 schools across 12 states in India. It is a popular voluntary organization and also associated with ICDS programme in Andhra Pradesh and providing food to pregnant women and children. Akshaya Patra has 43 kitchens spread across 12 states in India.

14. It is found that, Akshyapatra Foundation and Government of Andhra Pradesh spent Rs.73/(Breakfast, Lunch and Dinner) per a person for a day. The beneficiaries pay only Rs.15/- for breakfast, lunch and dinner, while the remaining cost of Rs.58/- spent by the government. The government of Andhra Pradesh allotted Rs.130 crores for this scheme.

15. The study found that the government is running 100 Anna Canteens in different places of Andhra Pradesh from July 2018 and they proposed to build more 103 Canteens in Andhra Pradesh very soon. The advantage of this scheme is permanent buildings. Many states are running this scheme through mobile canteens and vehicles.

16. It is found that the employees of the Anna Canteen should return the remaining food to Akshya Patra Foundation everyday; some days particularly at the time of rains many people are not walk-in to the Anna Canteens to access the scheme. Another reason is not access this scheme is self stig ma and availability of food at their homes.

17. Majority of the respondents stated that Anna Canteens are following the same type of cooking styles. Vegetables are changing but the cooking style is same in every day.

18. It is found that some employees in the Anna Canteen have aggressive behaviour. They are not receiving the beneficiaries in friendly manner. It may be an attitudinal problem. It should be changed through proper training

\section{Suggestions}

1. Majority of the respondents requested to start the parcel services. It may help to the aged, disabled, patients or others who may not walk in to the Anna Canteens.

2. As mentioned by many respondents standing in a $\mathrm{Q}$ is a difficult for the customers. Sometimes particularly at the time of lunch they have to stand in Q. They get the token after half-an-hour. Separate Q for women will be helpful to increase more women beneficiaries to Anna Canteens.

3. Majority of the respondents suggested that the cooking style of curries should be changed. Respondents expecting the fry curries, vegetable curries and pulusu curries. It may increase the interest among the beneficiaries

4. This scheme helps the unemployed youth. Through this scheme the youth may reach their goals. 
5. Involvement of self help groups in implementation of this scheme like Tamila Nadu is helpful to the wo men and their livelihood. The best SHGs may be involved.

6. Need more awareness about the programme.

7. Involve Corporate Companies under CSR to provide the food in Anna Canteens through public private partnerships.

8. Sunday is a holiday for Anna Canteens. Respondents suggest to make available the Anna Canteens on Sunday and some other festival days also.

\section{Social Work Perspective}

As Social Workers, we always think about the poverty, hunger, malnutrition and beggary. NTR Anna Canteen Scheme is one of the best schemes to reduce the poverty, malnutrition and hunger among the poor. Many people accessing this scheme and increasing their health standards. This scheme should be replicate to all over the world to remove the hunger deaths. The social workers should educate the poor people to access this scheme. The social workers should motivate the donors and corporate companies for the ir contributions to success the programme. Social Workers should educate the government to bring this program as Public Private Partnership Model.

\section{CONCLUSION}

NTR Anna Canteens is one of the best schemes in Andhra Pradesh introduced by Telugu Desam Party. It reached its objectives and the people who access the food in Anna Canteens are happy with the quality and quantity. Most importantly, poor people who cannot afford to have food at hotels by paying a high price are able to have a sumptuous meal for just Rs.5/-. It is helpful to the urban poor, unemployed youth, auto drivers and bachelors. Still the program needs some more awareness. It reduced the hungry of urban poor in Andhra Pradesh.

\section{REFERENCES}

[1] Government of Andhra Pradesh (2018) Municipal Administration \& Urban Development (Ubs) Department, G.O.MS.No. 185, Dated: 06-06-2018, Amaravathi, Andhra Pradesh.

[2] Tata Institute of Social Sciences (2018) Food and Welfare: A Case Study of Annapurna Canteens in Hyderabad, School Of Public Policy and Governance, Hyderabad Campus, Hy derabad.
[3] A.R. Nithya et al. (2018), Linchpins for Sustainability and Scalability of Hotel Industry: Amma Unavagam an Empirical Research, Sumedha Journal of Management, Vol.7, No.2, April-June 2018

[4] Ashok Kumar \& D. Krishnan (2013), Perceptions of Consumers towards "Amma Unavagum" with special reference to Vellore City, Tamilnadu, India, Impact, International Journal of Research in Business Management, Vol.1, Issue.5 October, 2013

[5] Dr. Satya Suresh (2017), Case Study, Amma Unavagam, Impact - Innovative Management Practices and Creative Thinking - A Journal for Management People, Issue 31, November 2017, Tirpur, India.

[6] Staff Reporter (2018), 100 Anna Canteens opened across Andhra Pradesh, Vijay awada, July 11, 2018 retrieved on 10.04.2019, https://www.thehindu.com/news/national/andhrapradesh/anna-canteens-laun ched-in-andhrapradesh/article24390237.ece

[7] Ashish Pandey (2018), CM Chandrababu Naidu launched 'Anna Canteen' in Andhra Pradesh, Hyderabad, India Today, July 11, 2018, retrieved on 11.04.2019. https://www.indiatoday.in/india/story/-cm-chandrababunaidu-laun ched-ann a-canteen-in-andhra-pradesh-12825392018-07-11

[8] Rudhran Baraasu (2018), Serving food to 3.5 lakh people daily through Amma canteens, Deccan Chronicle, Hyderabad, Retrieved on 11.04.2019 from https://www.deccanchronicle.com/nation/currentaffairs/240318/serving-food-to-35-lakh-people-dailythrough-amma-canteens.html

[9] Hindustan Times (2016), From Amma Canteens to Annapurna Rasois: Low price kitchens mushroom across India, Retrieved on 15.04 .2019 https://www.hindustantimes.com/india-news/from-ammacanteens-to-annapurna-rasois-low-price-kitchens-mushroomacross-country/story-XGla3f7iQqtU77vEE2zTOL.html

[10] PTI Jaipore (2016), Rajasthan launches Amma canteen-type meal scheme, Hindustan Times, Rajasthan, India. Retrieved from https://indianexpress.com/article/india/rajasthansubsidised-meal-scheme-4430800/

[11] Nikita Doval (2017), Tamil Nadu's Amma canteen concept catches on in other states, Hindustan Times Limited, Bangalore, India. Retrieved on 11.04.2019 from https://www.livemint.com/Politics/pHvjY4PHykVOy 7irb8H 2cO/Tamil-Nadus-Amma-canteen-concept-catches-on-inother-states.html

[12] https://www.akshay apatra.org/about-us

[13] https://www.facebook.com/AP.AnnaCanteen/ 